\title{
Role of physical attractiveness in impression formation $^{1}$
}

ARTHUR G. MILLER, Miami University, Oxford, Ohio 45056

Male and female judges were given photographs, previously scaled as high, moderate, or low in physical attractiveness, and were asked to record their impressions of the stimulus persons on an adjective checklist. The results showed high attractiveness to be associated with positive traits, the reverse holding for low attractiveness. The data are consistent with the hypothesis that, in a first-impression situation, a person's level of attractiveness may evoke in a perceiver a consistent set of expectancies by a process of trait inference. This kind of process accords well with previous research relating physical attractiveness to interpersonal processes.

Physical attractiveness has been a central independent variable in a number of recent studies. Using a gain-loss model of interpersonal attraction, Sigall \& Aronson (1969) predicted, and found, that highly attractive persons were strongly disliked if critical of naive Ss because of a greater initial drive to please attractive as opposed to unattractive individuals. Within the framework of Rotter's (1966) development of the internalexternal control construct, Miller (1970) found support for the prediction that unattractive persons would be perceived as external in their locus of control. Several investigators have found physical attractiveness to be a significant source of variance in interpersonal perception (e.g., Byrne, London, \& Reeves, 1968; Mills \& Aronson, 1965; Walster, Aronson, Abrahams, \& Rottman, 1966). In no case, however, has the underlying basis for the results been specified. One hypothesis is that attractiveness levels are perceptually related to certain psychological traits or dispositions. When attractiveness constitutes the initial stimulus input about another person, a set of expectancies regarding other aspects of that person may be activated by a process of trait inference (Bruner, Shapiro, \& Tagiuri, 1958, p. 278). This question was tested in the present study.

$$
\text { SUBJECTS }
$$

The Ss in this study were 360 male and 360 female undergraduates from introductory psychology courses at Miami University.

\section{PROCEDURE}

As part of another study (Miller, 1970), 200 male and 200 female photographs
Table 1

Means and Standard Deviations for Picture Sets

\begin{tabular}{|c|c|c|c|c|c|c|c|}
\hline \multirow{3}{*}{$\begin{array}{l}\text { Sex of } \\
\text { Judge }\end{array}$} & \multirow{3}{*}{$\begin{array}{l}\text { Sex of } \\
\text { Stimulus }\end{array}$} & \multicolumn{6}{|c|}{ Physical Attractiveness Level } \\
\hline & & \multicolumn{2}{|c|}{ High } & \multicolumn{2}{|c|}{ Moderate } & \multicolumn{2}{|c|}{ Low } \\
\hline & & Mean & SD & Mean & SD & Mean & $\mathrm{SD}$ \\
\hline Male & $\begin{array}{l}\text { Male } \\
\text { Female }\end{array}$ & $\begin{array}{l}5.92 \\
5.78 \\
6.62 \\
6.50\end{array}$ & $\begin{array}{l}1.78 \\
1.59 \\
1.45 \\
1.53\end{array}$ & $\begin{array}{l}4.56 \\
4.52 \\
4.34 \\
4.38\end{array}$ & $\begin{array}{l}1.56 \\
1.55 \\
1.56 \\
1.59\end{array}$ & $\begin{array}{l}3.11 \\
3.22 \\
2.14 \\
2.18\end{array}$ & $\begin{array}{l}1.25 \\
1.37 \\
1.28 \\
1.19\end{array}$ \\
\hline Female & $\begin{array}{l}\text { Male } \\
\text { Female }\end{array}$ & $\begin{array}{l}6.42 \\
6.46 \\
6.96 \\
7.00\end{array}$ & $\begin{array}{l}1.89 \\
1.76 \\
1.38 \\
1.61\end{array}$ & $\begin{array}{l}3.88 \\
3.90 \\
4.04 \\
4.12\end{array}$ & $\begin{array}{l}1.53 \\
1.54 \\
1.41 \\
1.41\end{array}$ & $\begin{array}{l}2.14 \\
2.26 \\
1.96 \\
1.72\end{array}$ & $\begin{array}{l}1.11 \\
1.16 \\
1.11 \\
0.83\end{array}$ \\
\hline
\end{tabular}

Table 2

Mean Adjective Scale Values for Each Dimension at Each Level of Attractiveness and Analysis of Variance $F$ Ratios for Male Judges

\begin{tabular}{|c|c|c|c|c|c|c|c|}
\hline \multirow[b]{2}{*}{ Dimension } & \multirow{2}{*}{$\begin{array}{c}\text { Sex of } \\
\text { Stimulus (S) }\end{array}$} & \multicolumn{3}{|c|}{ Physical Attractiveness (PA) } & \multirow[b]{2}{*}{$\mathrm{F}_{\mathrm{PA}}^{1}$} & \multirow[b]{2}{*}{$\mathrm{F}_{\mathrm{S}}^{2}$} & \multirow[b]{2}{*}{$\mathrm{F}_{\mathrm{PA}}^{3} \times \mathrm{S}$} \\
\hline & & High & Med & Low & & & \\
\hline $\begin{array}{l}\text { Indifferent: } \\
\text { Curious }\end{array}$ & $\begin{array}{l}\text { Male } \\
\text { Female }\end{array}$ & $\begin{array}{l}7.02 \mathrm{bc} \\
7.08 \mathrm{bc}\end{array}$ & $\begin{array}{l}7.53 \mathrm{c} \\
7.28 \mathrm{bc}\end{array}$ & $\begin{array}{l}6.25 \mathrm{~b} \\
4.30_{\mathrm{a}}\end{array}$ & $17.68 * *$ & $5.14 *$ & $3.99^{*}$ \\
\hline $\begin{array}{l}\text { Simple: } \\
\text { Complex }\end{array}$ & $\begin{array}{l}\text { Male } \\
\text { Female }\end{array}$ & $\begin{array}{l}5.63 \mathrm{~b} \\
7.12_{\mathrm{c}}\end{array}$ & $\begin{array}{l}5.98 \mathrm{~b} \\
6.00 \mathrm{~b}\end{array}$ & $\begin{array}{l}5.15 \mathrm{~b} \\
3.43_{\mathrm{a}}\end{array}$ & $22.75^{* *}$ & -- & $11.87^{* *}$ \\
\hline $\begin{array}{l}\text { Insensitive: } \\
\text { Perceptive }\end{array}$ & $\begin{array}{l}\text { Male } \\
\text { Female }\end{array}$ & $\begin{array}{l}7.08_{\mathrm{c}} \\
7.38_{\mathrm{c}}\end{array}$ & $\begin{array}{l}7.40_{\mathrm{c}} \\
6.83_{\mathrm{c}}\end{array}$ & $\begin{array}{l}5.27_{\mathrm{b}} \\
3.67_{\mathrm{a}}\end{array}$ & $43.65^{* *}$ & $5.18^{*}$ & $4.03^{*}$ \\
\hline $\begin{array}{l}\text { Careless: } \\
\text { Careful }\end{array}$ & $\begin{array}{l}\text { Male } \\
\text { Female }\end{array}$ & $\begin{array}{l}7.53 \mathrm{~b} \\
8.08 \mathrm{bc}\end{array}$ & $\begin{array}{l}8.57 \mathrm{c} \\
7.48 \mathrm{~b}\end{array}$ & $\begin{array}{l}5.72_{\mathrm{a}} \\
5.15_{\mathrm{a}}\end{array}$ & $34.24 * *$ & 1.67 & 2.89 \\
\hline $\begin{array}{l}\text { Practical: } \\
\text { Academic }\end{array}$ & $\begin{array}{l}\text { Male } \\
\text { Female }\end{array}$ & $\begin{array}{l}3.87 \mathrm{a} \\
5.22_{\mathrm{c}}\end{array}$ & $\begin{array}{l}4.38 \mathrm{ab} \\
5.02 \mathrm{bc}\end{array}$ & $\begin{array}{l}4.90 \mathrm{bc} \\
3.77_{\mathrm{a}}\end{array}$ & 1.06 & 1.91 & $12.92^{* *}$ \\
\hline $\begin{array}{l}\text { Calm: } \\
\text { Restless }\end{array}$ & $\begin{array}{l}\text { Male } \\
\text { Female }\end{array}$ & $\begin{array}{l}4.08 \\
3.97\end{array}$ & $\begin{array}{l}3.97 \\
4.53\end{array}$ & $\begin{array}{l}4.04 \\
4.08\end{array}$ & -- & -- & -- \\
\hline $\begin{array}{l}\text { Unsure: } \\
\text { Confident }\end{array}$ & $\begin{array}{l}\text { Male } \\
\text { Female }\end{array}$ & $\begin{array}{l}7.52 \mathrm{bc} \\
8.00_{\mathrm{c}}\end{array}$ & $\begin{array}{l}7.13 \mathrm{bc} \\
6.60 \mathrm{~b}\end{array}$ & $\begin{array}{l}4.75 \mathrm{a} \\
4.28 \mathrm{a}\end{array}$ & $52.95 * *$ & -- & 1.53 \\
\hline $\begin{array}{l}\text { Submissive: } \\
\text { Assertive }\end{array}$ & $\begin{array}{l}\text { Male } \\
\text { Female }\end{array}$ & $\begin{array}{l}5.05 \mathrm{bc} \\
5.82_{c}\end{array}$ & $\begin{array}{l}5.40_{c} \\
4.93_{b c}\end{array}$ & $\begin{array}{l}4.22 \mathrm{~b} \\
3.05_{\mathrm{a}}\end{array}$ & $15.94 * *$ & 1.06 & $4.05^{*}$ \\
\hline $\begin{array}{l}\text { Happy: } \\
\text { Sad }\end{array}$ & $\begin{array}{l}\text { Male } \\
\text { Female }\end{array}$ & $\begin{array}{l}1.53_{\mathrm{a}} \\
2.18 \mathrm{a}\end{array}$ & $\begin{array}{l}5.10 \mathrm{~b} \\
1.85 \mathrm{a}\end{array}$ & $\begin{array}{l}6.35 \mathrm{c} \\
5.18 \mathrm{~b}\end{array}$ & $61.10^{* *}$ & $18.73^{* *}$ & $15.08^{* *}$ \\
\hline $\begin{array}{l}\text { Passive: } \\
\text { Active }\end{array}$ & $\begin{array}{l}\text { Male } \\
\text { Female }\end{array}$ & $\begin{array}{l}7.70 \mathrm{bc} \\
7.85 \mathrm{c}\end{array}$ & $\begin{array}{l}6.92_{\mathrm{b}} \\
8.07_{\mathrm{c}}\end{array}$ & $\begin{array}{l}4.68 \mathrm{a} \\
4.07_{\mathrm{a}}\end{array}$ & $75.32 * *$ & -- & $4.15^{*}$ \\
\hline $\begin{array}{l}\text { Competitive: } \\
\text { Cooperative }\end{array}$ & $\begin{array}{l}\text { Male } \\
\text { Female }\end{array}$ & $\begin{array}{l}7.25_{\mathrm{c}} \\
7.80_{\mathrm{c}}\end{array}$ & $\begin{array}{l}6.13_{\mathrm{b}} \\
7.85_{\mathrm{c}}\end{array}$ & $\begin{array}{l}5.20 \mathrm{a} \\
6.28 \mathrm{~b}\end{array}$ & $17.91 * *$ & $19.99 * *$ & 1.82 \\
\hline $\begin{array}{l}\text { Aloof: } \\
\text { Amiable }\end{array}$ & $\begin{array}{l}\text { Male } \\
\text { Female }\end{array}$ & $\begin{array}{l}8.00_{c} \\
8.38_{c}\end{array}$ & $\begin{array}{l}6.48 \mathrm{~b} \\
8.52_{\mathrm{c}}\end{array}$ & $\begin{array}{l}5.32 \mathrm{a} \\
5.92 \mathrm{ab}\end{array}$ & $32.11^{* *}$ & $13.71^{* *}$ & $3.63^{*}$ \\
\hline $\begin{array}{l}\text { Candid: } \\
\text { Guarded }\end{array}$ & $\begin{array}{l}\text { Male } \\
\text { Female }\end{array}$ & $\begin{array}{l}4.00 \mathrm{bc} \\
3.68 \mathrm{ab}\end{array}$ & $\begin{array}{l}4.50 \mathrm{~cd} \\
3.03_{\mathrm{a}}\end{array}$ & $\begin{array}{l}4.98 \mathrm{~d} \\
3.85 \mathrm{bc}\end{array}$ & $4.27^{*}$ & $23.93 * *$ & 2.95 \\
\hline $\begin{array}{l}\text { Serious: } \\
\text { Humorous }\end{array}$ & $\begin{array}{l}\text { Male } \\
\text { Female }\end{array}$ & $\begin{array}{l}4.42_{\mathrm{d}} \\
4.17_{\mathrm{cd}}\end{array}$ & $\begin{array}{l}2.10_{\mathrm{a}} \\
4.57_{\mathrm{d}}\end{array}$ & $\begin{array}{l}3.07 \mathrm{~b} \\
3.45_{\mathrm{bc}}\end{array}$ & $9.42 * *$ & $15.98^{* *}$ & $14.33^{* *}$ \\
\hline $\begin{array}{l}\text { Self-control: } \\
\text { Pleasure-seek }\end{array}$ & $\begin{array}{l}\text { Male } \\
\text { Female }\end{array}$ & $\begin{array}{l}4.77 \mathrm{c} \\
5.05_{\mathrm{c}}\end{array}$ & $\begin{array}{l}2.67_{\mathrm{a}} \\
4.77_{\mathrm{c}}\end{array}$ & $\begin{array}{l}3.62 \mathrm{~h} \\
3.48 \mathrm{ab}\end{array}$ & $12.33 * *$ & $9.48^{* *}$ & $7.92^{* *}$ \\
\hline $\begin{array}{l}\text { Reserved: } \\
\text { Outspoken }\end{array}$ & $\begin{array}{l}\text { Male } \\
\text { Female }\end{array}$ & $\begin{array}{l}6.28 \mathrm{~d} \\
4.95 \mathrm{c}\end{array}$ & $\begin{array}{l}3.43_{\mathrm{ab}} \\
5.05_{\mathrm{c}}\end{array}$ & $\begin{array}{l}3.60 \mathrm{ab} \\
4.00_{\mathrm{bc}}\end{array}$ & $12.78^{* *}$ & -- & $7.82 * *$ \\
\hline $\begin{array}{l}\text { Rigid: } \\
\text { Flexible }\end{array}$ & $\begin{array}{l}\text { Male } \\
\text { Female }\end{array}$ & $\begin{array}{l}6.95 \mathrm{~b} \\
7.42 \mathrm{~b}\end{array}$ & $\begin{array}{l}4.57 \mathrm{a} \\
7.43 \mathrm{~b}\end{array}$ & $\begin{array}{l}5.22 \mathrm{a} \\
5.37_{\mathrm{a}}\end{array}$ & $17.35^{* *}$ & $19.20^{* *}$ & $10.48^{* *}$ \\
\hline
\end{tabular}

Note-Differences between means which do not have a subscript in common are significant at the .05 level or beyond. The second term of each bipolar dimension indicates the plus-keyed direction of each scale.

${ }^{*} p<.05 ;{ }^{* *} p<.01$

${ }^{1} d f=2,354 ;{ }^{2} d f=1,354 ; \quad{ }^{3} d f=2,354$ 
$\left(2 \frac{1}{2} \times 3 \frac{1}{2}\right.$ in.) were obtained from the yearbook office. These were professional photographs of senior students. One-hundred male and 100 female Ss rated each of the 400 pictures on a nine-point scale of physical attractiveness, one being extremely unattractive, nine being extremely attractive. Means and standard deviations were obtained for each picture, separately for male and female judges. From the distribution of means for each sex (of stimuli and judge), the upper, middle, and lower 10 photographs were selected. From each of these groups, the two photographs with the lowest standard deviation were chosen to represent the three ranges of physical attractiveness. The means and standard deviations of the stimuli are shown in Table 1.

In the present study, male Ss were supervised by a male experimenter (E), female Ss by a female E. The Ss were seen in groups of as many as four, although each $S$ was given individual instructions and worked in a separate cubicle. Each $\mathbf{S}$ was assigned randomly one of the 12 photographs relevant to his or her sex shown in Table 1 . The Ss were not informed of the physical attractiveness dimension.

Ss were asked to record their impressions of the person in the photograph on the Adjective Preference Scale (Jackson \& Minton, 1963). This scale consists of 17 dimensions (Tables 2 and 3 ), each of which contains 10 pairs of bipolar adjectives in forced-choice format. The score is the number in a particular direction checked on each scale (maximum 10). The psychometric status of this instrument is impressive, with Kuder-Richardson 20 reliabilities ranging from .55 to .96 (median .68) and low scale intercorrelations (generally well below .30).

\section{RESULTS AND DISCUSSION}

Scores on each dimension for the two photographs at each attractiveness level were combined. This procedure increases the representativeness of each attractiveness level, since any single photograph may evoke a variety of responses in the perceiver in addition to his impression of its attractiveness. For each of the 17 dimensions, a 2 by 3 analysis of variance was computed for the factors of stimulus sex and level of attractiveness. The cell means and $F$ ratios for male judges are shown in Table 2 and for female judges in Table 3.

For both groups of judges, there are significant effects for physical attractiveness in 15 of the 17 dimensions. A consistent pattern emerges, that of the unattractive person being associated with the negative or undesirable pole of the
Table 3

Mean Adjective Scale Values for Each Dimension at Each Level of Attractiveness and Analysis of Variance $F$ Ratios for Female Judges

\begin{tabular}{|c|c|c|c|c|c|c|c|}
\hline \multirow[b]{2}{*}{ Dimension } & \multirow{2}{*}{$\begin{array}{c}\text { Sex of } \\
\text { Stimulus }(\mathbf{S})\end{array}$} & \multicolumn{3}{|c|}{ Physical A ttractiveness (PA) } & \multirow[b]{2}{*}{$\mathbf{F}_{\mathbf{P A}}^{1}$} & \multirow[b]{2}{*}{$\mathrm{F}_{S}^{2}$} & \multirow[b]{2}{*}{$\mathrm{F}_{\mathrm{PA}}^{3} \times \mathrm{S}$} \\
\hline & & High & Med & Low & & & \\
\hline $\begin{array}{l}\text { Indifferent: } \\
\text { Curious }\end{array}$ & $\begin{array}{l}\text { Male } \\
\text { Female }\end{array}$ & $\begin{array}{l}8.08_{\mathrm{d}} \\
6.88_{\mathrm{bc}}\end{array}$ & $\begin{array}{l}6.70_{\mathrm{bc}} \\
6.47_{\mathrm{b}}\end{array}$ & $\begin{array}{l}7.78 \mathrm{~cd} \\
4.87 \mathrm{a}\end{array}$ & $5.27 * *$ & $22.48^{* *}$ & $6.58 * *$ \\
\hline $\begin{array}{l}\text { Simple: } \\
\text { Complex }\end{array}$ & $\begin{array}{l}\text { Male } \\
\text { Female }\end{array}$ & $\begin{array}{l}7.33 \mathrm{~d} \\
6.55 \mathrm{~cd}\end{array}$ & $\begin{array}{l}5.97_{b c} \\
5.37_{b}\end{array}$ & $\begin{array}{l}5.30 \mathrm{~b} \\
3.72 \mathrm{a}\end{array}$ & $24.14 * *$ & $11.95^{* *}$ & 1.11 \\
\hline $\begin{array}{l}\text { Insensitive: } \\
\text { Perceptive }\end{array}$ & $\begin{array}{l}\text { Male } \\
\text { Female }\end{array}$ & $\begin{array}{l}7.75_{\mathrm{c}} \\
7.65_{\mathrm{c}}\end{array}$ & $\begin{array}{l}6.32 \mathrm{~b} \\
7.08 \mathrm{bc}\end{array}$ & $\begin{array}{l}6.58 \mathrm{~b} \\
5.07 \mathrm{a}\end{array}$ & $16.22 * *$ & 1.11 & $6.12 * *$ \\
\hline $\begin{array}{l}\text { Careless: } \\
\text { Careful }\end{array}$ & $\begin{array}{l}\text { Male } \\
\text { Female }\end{array}$ & $\begin{array}{l}7.38 \mathrm{a} \\
8.28 \mathrm{~b}\end{array}$ & $\begin{array}{l}6.85 \mathrm{a} \\
8.92 \mathrm{~b}\end{array}$ & $\begin{array}{l}8.30_{\mathrm{b}} \\
6.58_{\mathrm{a}}\end{array}$ & 1.21 & 2.69 & $19.37 * *$ \\
\hline $\begin{array}{l}\text { Practical: } \\
\text { Academic }\end{array}$ & $\begin{array}{l}\text { Male } \\
\text { Female }\end{array}$ & $\begin{array}{l}4.75 \mathrm{~b} \\
4.73 \mathrm{~b}\end{array}$ & $\begin{array}{l}4.08 \mathrm{ab} \\
4.22 \mathrm{ab}\end{array}$ & $\begin{array}{l}4.45 \mathrm{~b} \\
3.68_{\mathrm{a}}\end{array}$ & $4.61^{*}$ & 1.20 & 1.98 \\
\hline $\begin{array}{l}\text { Calm: } \\
\text { Restless }\end{array}$ & $\begin{array}{l}\text { Male } \\
\text { Female }\end{array}$ & $\begin{array}{l}4.88_{\mathrm{d}} \\
4.27 \mathrm{bcd}\end{array}$ & $\begin{array}{l}4.33_{\mathrm{cd}} \\
3.55_{\mathrm{ab}}\end{array}$ & $\begin{array}{l}3.83 \mathrm{abc} \\
3.50_{\mathrm{a}}\end{array}$ & $6.86^{* *}$ & $7.92 * *$ & -- \\
\hline $\begin{array}{l}\text { Unsure: } \\
\text { Confident }\end{array}$ & $\begin{array}{l}\text { Male } \\
\text { Female }\end{array}$ & $\begin{array}{l}7.97 \mathrm{de} \\
8.42_{\mathrm{e}}\end{array}$ & $\begin{array}{l}7.13_{\mathrm{cd}} \\
6.85_{\mathrm{c}}\end{array}$ & $\begin{array}{l}5.13_{\mathrm{b}} \\
4.20_{\mathrm{a}}\end{array}$ & $61.25^{* *}$ & -- & 2.28 \\
\hline $\begin{array}{l}\text { Submissive: } \\
\text { Assertive }\end{array}$ & $\begin{array}{l}\text { Male } \\
\text { Female }\end{array}$ & $\begin{array}{l}6.02 \mathrm{c} \\
5.47 \mathrm{bc}\end{array}$ & $\begin{array}{l}5.15 \mathrm{bc} \\
3.57 \mathrm{a}\end{array}$ & $\begin{array}{l}4.93 \mathrm{~b} \\
3.02 \mathrm{a}\end{array}$ & $14.93 * *$ & $23.63^{* *}$ & 2.19 \\
\hline $\begin{array}{l}\text { Happy: } \\
\text { Sad }\end{array}$ & $\begin{array}{l}\text { Male } \\
\text { Female }\end{array}$ & $\begin{array}{l}1.97_{\mathrm{b}} \\
1.97_{\mathrm{b}}\end{array}$ & $\begin{array}{l}2.82 \mathrm{~b} \\
0.85_{\mathrm{a}}\end{array}$ & $\begin{array}{l}4.15_{\mathrm{c}} \\
5.12_{\mathrm{d}}\end{array}$ & $42.52 * *$ & 1.42 & $9.52 * *$ \\
\hline $\begin{array}{l}\text { Passive: } \\
\text { Active }\end{array}$ & $\begin{array}{l}\text { Male } \\
\text { Female }\end{array}$ & $\begin{array}{l}8.22 \mathrm{de} \\
8.37 \mathrm{e}\end{array}$ & $\begin{array}{l}7.20 \mathrm{bc} \\
7.57 \mathrm{~cd}\end{array}$ & $\begin{array}{l}6.77 \mathrm{~b} \\
4.62 \mathrm{a}\end{array}$ & $47.01^{* *}$ & $6.00^{*}$ & $13.13 * *$ \\
\hline $\begin{array}{l}\text { Competitive: } \\
\text { Cooperative }\end{array}$ & $\begin{array}{l}\text { Male } \\
\text { Female }\end{array}$ & $\begin{array}{l}6.97 \mathrm{ab} \\
7.48 \mathrm{ab}\end{array}$ & $\begin{array}{l}6.60 \mathrm{a} \\
8.92 \mathrm{c}\end{array}$ & $\begin{array}{l}6.73_{\mathrm{ab}} \\
7.65 \mathrm{~b}\end{array}$ & 2.18 & $25.25^{* *}$ & $4.81^{* *}$ \\
\hline $\begin{array}{l}\text { Aloof: } \\
\text { Amiable }\end{array}$ & $\begin{array}{l}\text { Male } \\
\text { Female }\end{array}$ & $\begin{array}{l}8.52 \mathrm{bc} \\
7.90 \mathrm{~b}\end{array}$ & $\begin{array}{l}7.03_{\mathrm{a}} \\
9.17_{\mathrm{c}}\end{array}$ & $\begin{array}{l}6.70_{\mathrm{a}} \\
7.02 \mathrm{a}\end{array}$ & $11.70^{* *}$ & $5.83^{*}$ & $10.17^{* *}$ \\
\hline $\begin{array}{l}\text { Candid: } \\
\text { Guarded }\end{array}$ & $\begin{array}{l}\text { Male } \\
\text { Female }\end{array}$ & $\begin{array}{l}3.63_{\mathrm{ab}} \\
5.07_{\mathrm{c}}\end{array}$ & $\begin{array}{l}3.92 \mathrm{~b} \\
3.02 \mathrm{a}\end{array}$ & $\begin{array}{l}4.02 \mathrm{~b} \\
3.80 \mathrm{~b}\end{array}$ & $5.84 * *$ & -- & $10.73^{* *}$ \\
\hline $\begin{array}{l}\text { Serious: } \\
\text { Humorous }\end{array}$ & $\begin{array}{l}\text { Male } \\
\text { Female }\end{array}$ & $\begin{array}{l}4.48_{\mathrm{c}} \\
4.33_{\mathrm{c}}\end{array}$ & $\begin{array}{l}3.72 \mathrm{bc} \\
3.37_{\mathrm{b}}\end{array}$ & $\begin{array}{l}2.33 \mathrm{a} \\
2.02 \mathrm{a}\end{array}$ & $27.95^{* *}$ & 1.23 & -- \\
\hline $\begin{array}{l}\text { Self-control: } \\
\text { Pleasure-seek }\end{array}$ & $\begin{array}{l}\text { Male } \\
\text { Female }\end{array}$ & $\begin{array}{l}5.92 \mathrm{~d} \\
4.77 \mathrm{c}\end{array}$ & $\begin{array}{l}4.62 \mathrm{c} \\
2.93 \mathrm{~b}\end{array}$ & $\begin{array}{l}2.18_{\mathrm{ab}} \\
1.97 \mathrm{a}\end{array}$ & $59.49^{* *}$ & $17.28^{* *}$ & $3.07 *$ \\
\hline $\begin{array}{l}\text { Reserved: } \\
\text { Outspoken }\end{array}$ & $\begin{array}{l}\text { Male } \\
\text { Female }\end{array}$ & $\begin{array}{l}6.32 \mathrm{~b} \\
5.28 \mathrm{~b}\end{array}$ & $\begin{array}{l}5.55 \mathrm{~b} \\
2.70_{\mathrm{a}}\end{array}$ & $\begin{array}{l}2.53_{a} \\
1,68 \mathrm{a}\end{array}$ & $53.83^{* *}$ & $29.41^{* *}$ & $4.81 * *$ \\
\hline $\begin{array}{l}\text { Rigid: } \\
\text { Flexible }\end{array}$ & $\begin{array}{l}\text { Male } \\
\text { Female }\end{array}$ & $\begin{array}{l}7.00 \mathrm{bc} \\
6.67_{\mathrm{b}}\end{array}$ & $\begin{array}{l}6.13_{b} \\
7.87_{c}\end{array}$ & $\begin{array}{l}4.72 \mathrm{a} \\
6.10 \mathrm{~b}\end{array}$ & $13.33^{* *}$ & $11.25^{* *}$ & $5.33^{* *}$ \\
\hline
\end{tabular}

Note-Differences between means which do not have a subscript in common are significant at the .05 level or beyond. The second term of each bipolar dimension indicates the plus-keyed direction of each scale.

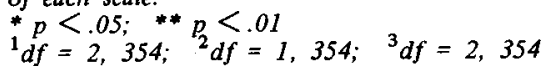

adjective scales and the highly attractive person being judged significantly more positively. The status of moderately attractive persons is variable, generally falling between the high- and low-attractive stimuli, but not significantly different from both extremes. Physical attractiveness, thus, is a potentially strong determinant of first impressions. The effect is pervasive, occurring in a large array of impression responses and with respect to male and female stimulus persons. That male and female judges responded to different sets of photographs serves as a kind of replication and adds to the generality of the findings.

There are a number of significant effects for the sex of the stimulus persons. Some reflect sex-role stereotypes, e.g., female judges perceiving females as more simple, submissive, passive, and reserved, whereas other sex effects seem to lack psychological meaning or generality, e.g., male judges seeing males as significantly

Regarding the Sex by Attractiveness interactions, examination of the pairs of cells at each attractiveness level reveals seven significant differences between male and female photographs at the high-attractive level, 20 at the moderate-attractive level, and 18 at the low-attractive level. It appears that as one departs from high-physical attractiveness, a stimulus person's sex becomes a more influential impression determinant. However, as previously stated, the precise meaning or significance of different impressions of male and female stimulus persons is not always clear. Introducing a more sad than females. 
behavioral consequence of the first impression response might clarify the implications of such interaction effects. A plausible hypothesis in this context might be that unattractive males are perceived more adept at compensating for their unattractiveness than are females, i.e., if one must be unattractive, it is a better fate to be male than female.

Most significant, in view of the present data, is the relative paucity of experimental interest in the attractiveness variable, as Sigall \& Aronson (1969, p. 93) have indicated. For it seems quite probable that this dimension has real significance as an antecedent of "liking" or interpersonal attraction, in addition to such well-studied factors as propinquity (Newcomb, 1961), cognitive balance (Aronson \& Cope, 1968), and attitude similarity-dissimilarity (Byrne, Clore, \& Griffitt, 1967). Questions suggestive of needed research are: When do the trait implications of physical attractiveness appear, developmentally, and what are the sources of these relationships? To what extent are correlates of physical attractiveness empirically based, in addition to being assumed, as shown in the present data? Does attractiveness influence social interaction in the manner of a self-fulfilling prophecy, i.e., if unattractive persons are perceived as inadequate on personality factors, are such assumed correlates subsequently "validated" in interaction? What social context and individual difference factors increase or decrease the importance of-or interact with-the attractiveness variable?

\section{REFERENCES}

ARONSON, E., \& COPE, V. My enemy's enemy

is my friend. Journal of Personality \& Social

Psychology, 1968, 8, 8-12.
BRUNER, J. S., SHAPIRO, D., \& TAGIURI, R. The meaning of traits in isolation and in combination. In R. Tagiuri and L. Petrullo (Eds.), Person perception and interpersonal behavior. Stanford: Stanford University Press, 1958. Pp. 276-288.

BYRNE, D., CLORE, G. L., JR., \& GRIFFITT, W. Response discrepancy versus attitude similarity-dissimilarity as determinants of attraction. Psychonomic Science, 1967, 7, 397-398.

BYRNE, D., LONDON, O., \& REEVES, K. The effects of physical attractiveness, sex, and attitude similarity on interpersonal attraction. Journal of Personality, 1968, 36, 259-271.

JACKSON, D. N., \& MINTON, H. L. A forced-choice adjective preference scale for personality assessment. Psychological Reports, $1963,12,515-520$.

MILLER, A. G. Social perception of internal-external control. Perceptual \& Motor Skills, $1970,30,103-109$.

MILLS, J., \& ARONSON, E. Opinion change as a function of the communicator's attractiveness and desire to influence. Journal of Personality \& Social Psychology, 1965, 1, 173-177.

NEWCOMB, T. M. The acquaintance process. New York: Holt, Rinehart, \& Winston, 1961.

ROTTER, J. B. Generalized expectancies for internal versus external control of reinforcement. Psychological Monographs, 1966, 80, 1(Whole No. 609).

SIGALL, H., \& ARONSON, E. Liking for an evaluator as a function of her physical attractiveness and nature of the evaluations. Journal of Experimental Social Psychology, $1969,5,93-100$

WALSTER, E., ARONSON, V., ABRAHAMS, D., \& ROTTMANN, L. Importance of physical attractiveness in dating behavior. Journal of Personality \& Social Psychology, 1966, 4, 508-516.

\section{NOTE}

1. The writer would like to thank Wesley Penn and Betty Jerger for their assistance and David Probert of the Miami University Computing Center. when compared to appropriate control strings that lacked either of them. Bogartz and Arlinsky, however, did not include a control condition in which both function words and bound morphemes were present but not in syntactic order. O'Connell, Turner, \& Onuska (1968), using orally presented strings in which such a control was present, found that syntax did not facilitate recall. Further negative findings were reported by Rosenberg (1964), who found that the addition of bound morphemes in syntactic order to short (five-unit) strings did not facilitate their immediate recall. Bryk \& O'Connell (1967), using strings (10 units) adopted from Epstein's (1961) original strings, tested for immediate recall under three levels of constraint: no morphology and no syntax (NS), morphology alone (LS), and morphology and syntax (HS). They found that the high structure condition (morphology and syntax) was significantly different from the condition of no structure. The difference between the high and low levels of structure was nonsignificant.

Consideration of the available evidence suggests that the influence of syntactic and/or morphological cues may, among other things, be dependent upon the length of the string itself. Bryk (1968) suggests that syntactic facilitation may occur primarily because of " $S$ 's facility in organizing the individual items in a string to form more easily storable and recallable chunks of information [p. 3]." Extending Miller's (1956) concept of chunking, Bryk states that the advantages of grammatical structure should increase as the amount of information to be stored increases. Thus, for relatively longer strings "prechunked" syntactic strings should be more apparent than for the relatively shorter strings. In a 3 by 3 by 3 factorial design, Bryk used immediate written recall of nonsense strings to study the effects of: structure (NS, LS, HS), meaningfulness of nonsense stems, and string length $(5,9,12)$. He states that his results revealed that recall of $\mathrm{HS}$ strings relative to NS and LS strings increased as a function of increases in the meaningfulness and length of the nonsense string. His failure to find syntactic facilitation for the five-unit strings suggests that previous failures (e.g., Rosenberg) to find such facilitation are explainable in light of the relatively short string length used. However, careful examination of the procedure and results leads to a different interpretation. Since the lengths of strings contained different numbers of items, analysis of the mean number of items recalled, rather than the percentage of items recalled, indicates a possible confounding. It is impossible to determine 